\title{
Justicia, mercado y precio en Francisco de Vitoria*
}

\section{Justice, Market and Price in Francisco de Vitoria}

\author{
JosÉ LUIS CENDEJAS BUENO \\ jl.cendejas@ufv.es \\ Universidad Francisco de Vitoria \\ Ctra. Pozuelo-Majadahonda, km. 1,800. \\ 28223 Pozuelo de Alarcón (Madrid).
}

Resumen: Para Vitoria, lo justo en los intercambios no resulta del mero consentimiento, sino que han de darse las condiciones que permiten hablar de un acto plenamente voluntario: ausencia de fraude y engaño, que causan ignorancia, y que el vendedor o el comprador no se aprovechen de la situación de necesidad del otro lado del mercado. Estos son los prerrequisitos fundamentales de una compraventa lícita y el fundamento del precio justo basado en la común estimación. El lucro en la actividad mercantil es lícito si ésta sirve a la comunidad familiar o política, si "añade algo" y si la mera ganancia no se toma como fin en sí mismo. Además de darse estas razones, el lucro ha de resultar de comprar y vender a precios justos. En definitiva, el intercambio entre iguales, propio de la justicia conmutativa, exige el intercambio de cosas equivalentes, constituyendo éste un principio de derecho natural.

Palabras clave: Pensamiento económico de la Escolástica, pensamiento económico de Francisco de Vitoria, Justicia conmutativa, Precio justo, Lucro
Abstract: For Vitoria, fairness in exchanges does not result from mere consent, but conditions that allow us to speak of a fully voluntary act must be verified: absence of fraud and deceit, which cause ignorance, and that the seller or the buyer do not take advantage of the situation of need on the other side of the market. These are the fundamental prerequisites of a lawful purchase and the basis of the just price formed from the common estimate. Profit in trading activity is lawful if this serves the family or political community, if it "adds something" and if the mere profit is not taken as an end in itself. In addition to these reasons, the profit is lawful if it results from buying and selling at just prices. In short, the exchange between equal people, characteristic of the commutative justice, requires the exchange of equivalent things, this being a principle of natural law.

Keywords: Scholastic Economic Thought, Francisco de Vitoria's Economic Thought, Commutative Justice, Just Price, Enrichment

* Este trabajo es resultado del proyecto "Sociedad, política y economía: proyecciones de la Escolástica española en el pensamiento británico y anglosajón” (Programa Estatal de Fomento de la Investigación Científica y Técnica de Excelencia, referencia: FFI2017-84435-P). El autor agradece también los comentarios de los evaluadores que han contribuido a mejorar este trabajo. 


\section{INTRODUCCIÓN}

Desde la perspectiva del pensamiento económico, la denominación de Escuela de Salamanca se encuentra en el capítulo III del discurso de recepción como académico de Ciencias Morales y Políticas de José Larraz titulado "El cuantitativismo monetario de Salamanca"1. Sobre este trabajo llamó la atención el profesor Viñas y Mey a Marjorie Grice-Hutchinson ${ }^{2}$ quien fue la encargada de dar a conocer a Hayek, su director de tesis, la existencia e importancia de esta Escuela ${ }^{3}$. El libro de Grice-Hutchinson, The School of Salamanca: Readings in Spanish Monetary Theory, 1544-1605, de 1952, inicia, en el ámbito del pensamiento económico, el interés más reciente por los escolásticos españoles del siglo XVI. En esta obra se describe cómo estos doctores y otros autores no pertenecientes a la Escuela de Salamanca en sentido estricto (la lista comprende Francisco de Vitoria, Domingo de Soto, Juan de Medina, Martín de Azpilcueta, Diego de Covarrubias, Luis Saravia de la Calle ${ }^{4}$, Tomás de Mercado, Francisco García, González de Cellorigo, Pedro de Valencia y Luis de Molina) desarrollaron una teoría del valor basado en la apreciación subjetiva, analizaron la formación competitiva de los precios y llegaron a establecer los fundamentos de la teoría cuantitativa del dinero, por ejemplo, Azpilcueta ${ }^{5}$ en 1556, 12 años antes que Bodin (Réponses au Paradoxes de M. de Malestroit touchant le fait des monnaies et l'enrichissement de toutes choses, 1568) y de modo más claro que Copérnico en 1526 (Monetae cudendae ratio), así como la teoría de la paridad del poder adquisitivo (anticipando a Cassel como señala Larraz) para explicar los tipos de cambio ${ }^{6}$, algo que Bodin no llegó a plantear.

Conforme se deduce de Grice-Hutchinson (1952), Schumpeter (1954) y de Roover (1955), el pensamiento económico de la Escolástica parte de Aris-

1 Larraz, J. (1943). Aunque no es Larraz el creador del término, véase Zorroza, M. I. (2013), nota a pie $n^{\circ} 6$.

2 Grice-Hutchinson, M. (1989).

3 Gómez Rivas, L. (2002).

4 Autor de Instrucción de mercaderes muy provechosa (Medina del Campo, 1544). Coincide este tratado con la publicación de otros dos sobre cambios y usura: Tratado de cambios y reprobación de usura (Valladolid, 1542) de Cristóbal de Villalón y Tratado de los préstamos (Toledo, 1543) de Luis de Alcalá. Los tres describen las consecuencias del fenómeno inflacionario que vive Castilla y que afecta a precios y cambios, pero lo atribuyen a las prácticas mercantiles y no al aumento de la cantidad de dinero, a diferencia de los escolásticos de Salamanca. Véase Reeder, J. (2008).

5 En su Comentario resolutorio de cambios, apéndice del Manual de Confesores y Penitentes.

6 Muy buenas síntesis del pensamiento económico de la Escuela de Salamanca son Grice-Hutchinson, M. (1952, 1978, 1993, 1999), Gómez Camacho, F. (1998, 1999), Tedde, P. y Perdices, L. (1999), del Vigo, A. (1997) y Alves, A. A. y Moreira, J. M. (2013). 
tóteles, e inserto en el pensamiento político y jurídico, pasó a los iusnaturalistas protestantes (Grocio, Hobbes, Locke y Pufendorf) hasta llegar a Hutcheson, maestro de Smith. Siguiendo la trayectoria señalada, el pensamiento escolástico influyó en la Economía Clásica inglesa (sin olvidar otras influencias como la de la fisiocracia francesa) sobre todo en lo que concierne a la pretensión teórica del análisis, algo que no está presente del mismo modo en el pensamiento mercantilista ${ }^{7}$. Así, tras la "mano invisible" de Smith subyace un principio de orden social que se corresponde con un iusnaturalismo secularizado, aunque su teoría del valor no sea la subjetiva de la Escolástica.

Por lo que respecta a la teoría del valor, de las dos teorías fundamentales, la basada en la necesidad tal como es percibida subjetivamente, y la basada en los costes incorporados, ya rebatida por Saravia de la Calle ${ }^{8}$, fue la segunda la que prevaleció a lo largo del siglo XIX, siendo desarrollada por Smith, Ricardo o Marx, hasta que finalmente la revolución marginalista, en torno a 1870, restableció el enfoque subjetivo. A esto se refiere Schumpeter en la sección titulada "La economía y la sociología escolásticas" al hablar de "rodeo derrochador de tiempo y de esfuerzo". El reconocimiento de la aportación española de esta Escuela al pensamiento económico ha quedado finalmente reflejado en las historias del pensamiento económico ${ }^{10}$, y ocupa un lugar central en Rothbard (1995) y, por supuesto, en Fuentes Quintana (1999).

Aunque, desde el pensamiento económico, han recibido más atención otros autores, correspondió a Francisco de Vitoria ser el maestro y fundador reconocido de la Escuela teológica de Salamanca ${ }^{11}$ y renovador de su enseñanza al implantar la Suma de Teología de Tomás de Aquino como referencia fundamental con preferencia sobre las Sentencias de Pedro Lombardo, así como el dictado de sus lecciones como método de enseñanza. En la Suma basaba el dictado de sus lecciones ordinarias mientras que las Relecciones ${ }^{12}$, conforme a los usos de la Universidad, eran conferencias reservadas para los prin-

7 Schumpeter diferencia el pensamiento económico, de tipo analítico, de la Escolástica de un pensamiento sobre cuestiones económicas de carácter más práctico, que es el llevado a cabo por los "consultores y panfletistas". Los arbitristas serían el correlato español de estos últimos. Véase la interpretación que ofrece Martín, V. (2000) de estos dos paradigmas en el caso español.

8 Grice-Hutchinson, M. (1952), p. 48.

9 Schumpeter, J. A. (1954), p. 97.

10 Por ejemplo, en Gordon, B. (1975), Baeck, L. (1994) y Perdices, L. (2008).

11 Belda Plans, J. (2000), p. 157; Barrientos, J. (2005, 2011); Pena González, M. A. (2009), pp. 52-53; Zorroza, M. I. (2013).

12 Se conservan trece de las quince Relecciones pronunciadas. En 2017 la editorial San Esteban publicó una edición bilingüe comentada de todas ellas, dirigida por A. Osuna Fernández-Largo. 
cipales festivos del año. El núcleo de la Escuela estaba constituido por un triángulo en el que se encontraban la propia Universidad, el convento dominico de San Esteban y el Colegio de San Gregorio en Valladolid. Vitoria, conociendo de primera mano el nominalismo y el humanismo renacentista debido a su estancia en la Universidad de París, propició a su vuelta a España (en 1523 al colegio de San Gregorio, y desde 1526 desde la Cátedra de Prima de Teología de Salamanca) la difusión de la obra de Tomás de Aquino y dio respuesta satisfactoria al reto intelectual que suponía el descubrimiento de los pueblos americanos.

Aclarar qué se debía en justicia a los indios recién descubiertos constituía un reto científico de primera magnitud que Vitoria supo abordar estableciendo los fundamentos del hoy denominado derecho internacional ${ }^{13}$ cuya base no es otra que el tradicional derecho de gentes. En este sentido Vitoria ocupa un lugar preeminente sobre Hugo Grocio que, con toda propiedad, podríamos calificar de discípulo suyo ${ }^{14}$. Como consecuencia de que se reconoce como "sujeto de derecho" - dicho en términos actuales - al indio americano, se acepta, como paso lógico subsiguiente, la existencia de una comunidad política universal que incluye todos los pueblos - communitas totius orbis - y de un correspondiente bien común universal, patente en las Relecciones De Indis recenter inventis y De iure belli Hispanorum in barbaros, ambas de 1539. Posteriormente a la aportación vitoriana, tendrá lugar en torno al Colegio de San Gregorio, en 1550 y 1551, la polémica de los naturales que, entre otros miembros de la Escuela, enfrentó a Sepúlveda (De iustis belli causis apud indios, 1550) y Las Casas (Treinta proposiciones muy jurídicas, 1552). En general, la "duda indiana" era una pregunta sobre la legitimidad de la conquista y la evangelización que cuestionaba, no solo los procedimientos, sino también el hecho de someter a los pueblos descubiertos a la jurisdicción de un príncipe foráneo, cuando era evidente que éstos disponían de dominio para autogobernarse y eran dueños legítimos de sus bienes.

13 El "redescubrimiento" de la obra de Vitoria en el ámbito del derecho internacional comienza con los trabajos de Brown Scott y Nys a principios del s. XX. Véanse, por ejemplo, las referencias bibliográficas recogidas por Pena González, 2009, p. 384; también la misma obra para una descripción detallada de la rehabilitación de la Escuela en otros ámbitos del saber a lo largo del siglo XX, especialmente el teológico.

14 Tanto en el De Mare Liberum (1609) (capítulo XII del De iure praedae) como en el De iure belli ac pacis (1625), Grocio cita con frecuencia a Vitoria, Vázquez de Menchaca y Covarrubias, entre otros escolásticos españoles. Véanse al respecto los trabajos de Gómez Rivas, L. (2004, 2005a, 2005b). 
El descubrimiento trajo además consigo importantes cambios económicos ligados a una doble expansión, de un lado de los intercambios comerciales, de otro, de la masa monetaria debido a las remesas de oro, y sobre todo plata, que llegaban de las minas americanas. Con la entrada de la plata americana y las innovaciones financieras y bancarias de la época, van a estar disponibles los medios de pago necesarios para acelerar la transformación económica de Europa y conformar el luego denominado capitalismo mercantil. En los siglos XVI y XVII están presentes fenómenos como la inflación y la depreciación de la moneda debidos a la expansión monetaria, la financiación del déficit público y la carga de la deuda. Era preciso financiar el Imperio al tiempo que mantener la paz social; de ahí el intervencionismo sobre el precio del trigo sujeto a los vaivenes de las sequías periódicas de la cuenca mediterránea. Estos hechos serán objeto de atención por parte de los escolásticos españoles que abordaron su análisis desde el tomismo que Francisco de Vitoria había importado de París. Cuando los escolásticos se enfrentan tanto a la conquista y evangelización de América como a unos nuevos "tratos y contratos", la pregunta a la que tratan de dar respuesta es la misma: cuál es el modo justo de proceder.

Teniendo en cuenta este contexto, este trabajo aborda el análisis que Vitoria realiza sobre la justicia en los intercambios como ejemplo paradigmático del enfoque seguido por otros miembros de la Escuela de Salamanca ${ }^{15}$. Para ello procedemos del siguiente modo. En la sección segunda exponemos el enfoque metodológico de Vitoria, común a la Escuela. En la sección tercera abordamos su concepción sobre el derecho y la propiedad, y en la cuarta nos centramos en la justicia en los intercambios destacando los aspectos relativos al precio justo y al lucro. Tomamos como referencia las lecciones ordinarias ${ }^{16}$ de Vitoria donde comenta las cuestiones sobre la justicia y el derecho (tratado De iustitia et iure) de la Secunda Secundae ${ }^{17}$ de la Suma Teológica de Tomás de

15 Castillo, G. y Zorroza, M. I. (2015) destacan el valor antropológico de la aportación del pensamiento económico de Vitoria en comparación con el paradigma del homo oeconomicus que se encuentra en la actualidad profundamente cuestionado. Asimismo, véanse Iparraguirre, D. (1957) y González Fabre, R. (1998) que desarrollan aspectos que aquí no podemos tratar con la extensión debida.

16 Éstas se conocen gracias a los apuntes de sus alumnos ya que Vitoria no las publicó en vida, de ahí la importancia que ha tenido el trabajo de edición y traducción basado en estos manuscritos como el llevado a cabo en su día por Beltrán de Heredia (1932-1935 y 1952). Vitoria explicó el De iustitia et iure (qq. 57-79 de la II-II) en los cursos 1527-1528 y 1535-1536. El manuscrito 43 de la Universidad de Salamanca, obra del bachiller Francisco Trigo, corresponde al curso 1935-36. En él se basa la edición de Beltrán de Heredia y las que parten de ella.

17 Además de Vitoria, comentaron la Secunda, Domingo de Soto, Bartolomé de Medina, Domingo Báñez, fray Luis de León, Juan de Guevara, Pedro de Aragón, Gregorio de Valencia, Luis de Molina, Francisco Suárez y Gabriel Vázquez (Langella, S., 2011, p. 34). Véanse también Folgado, A. (1959) y Barrientos, J. (2001). 
Aquino (STh, en adelante). La reflexión sobre el derecho y la justicia, la propiedad y la realización de lo justo en los intercambios mercantiles tiene su lugar en los comentarios a las siguientes cuestiones de la Suma: cc. 57, 58 y 61 para lo relativo al derecho, la justicia y sus $\operatorname{partes}^{18}$, la c. 66 sobre la propiedad $^{19}$ y la c. 77 sobre la compraventa ${ }^{20}$. Con el fin de apreciar la aportación de los comentarios de Vitoria nos referiremos, cuando sea preciso, a lo dicho por Tomás de Aquino.

\section{LA INVESTIGACIÓN SOBRE “LO JUSTO” EN FRANCISCO DE VITORIA Y LA ESCUELA DE SALAMANCA}

A pesar de la importancia de sus aportaciones al pensamiento económico, en sentido estricto, la Escuela de Salamanca no es una escuela de pensamiento económico sino principalmente teológico. Como afirma Francisco de Vitoria en De potestate civili (1528) "tan dilatado es el oficio y la misión del teólogo, que ningún argumento, ninguna controversia, ninguna materia pueden considerarse ajenos a su profesión". Sin embargo, no ha de pensarse por ello que las cuestiones de análisis económico se aborden directamente desde la teología, sino mediando una concepción de "lo justo natural" a partir de la cual se analizan, entre otros asuntos, los intercambios mercantiles. Este proceder es común a toda la Escolástica.

Desde Aristóteles y hasta el siglo XVIII, los temas que actualmente calificamos de económicos ${ }^{21}$ se consideran en relación a la virtud de la justicia ${ }^{22}$ y

18 Seguimos la edición de Frayle, L. (2001).

19 Edición de Sierra Bravo, R. (1975), vol. 2, pp. 600-603.

20 Zorroza, M. I. (2006). Dejamos para otro trabajo el comentario de Vitoria a la c. 78 sobre la usura. La ilicitud de la usura se basa en el hecho de que en el dinero no es posible separar uso y propiedad, por lo que no puede recibirse "algo más" aparte de la cuantía del préstamo. No existe un "precio justo" en la usura, o dicho de otro modo, el precio del dinero es nulo. Otra cosa distinta es el pago de un interés por razones ajenas al dinero, esto es, por algún título extrínseco.

21 Aunque, en el mundo griego, el término más próximo a lo que se entiende hoy en día por economía sea el de crematística. "Lo económico" se refiere originalmente a las leyes (nomos) de la casa (oikos). En la Grecia clásica esta incluía tanto los bienes como las personas, libres y esclavas, bajo la potestad del cabeza de familia, lo que denominaríamos familia y patrimonio familiar, unidad de personas y bienes (así en Aristóteles, Política I). La economía, en tanto administración de la casa, debe diferenciarse de la crematística o "arte adquisitivo". Lo propio de la crematística es la adquisición de bienes útiles para la administración de la casa pues le procura bienes indispensables para la vida, mientras que lo propio de la economía es el uso de dichos bienes (Política I, 8, 1256a2). Partes de la crematística son el pastoreo, la agricultura, la piratería, la pesca, la caza y el intercambio (Política I, 8, 1256b8).

22 El trato mercantil compete a la justicia conmutativa en cuyo seno se analizan, por ejemplo, la naturaleza de la propiedad, el precio justo y la usura. 
este es precisamente el enfoque de Vitoria. Hay otros ámbitos en los que se tratan cuestiones de interés para entender el pensamiento económico escolástico, como por ejemplo, cuando se consideran las virtudes de la prudencia, de la caridad o de la liberalidad, pero es de la virtud de la justicia de la que depende más directamente la vida en sociedad. "Lo justo natural", como el conjunto de la ley natural, es aprehensible racionalmente mediante la recta ratio ${ }^{23}$, y en esto se fundamenta el pensamiento escolástico y vitoriano. Por ser naturalmente justo, en la compraventa se han de intercambiar cosas iguales en su común estimación, y es la pregunta sobre las condiciones que permiten llegar a esa común estimación donde encuentra su lugar el análisis económico.

De modo análogo a las dudas morales y jurídicas derivadas de la conquista de los pueblos americanos, las oportunidades de enriquecimiento creadas por la expansión económica y las nuevas prácticas financieras suscitaban dudas morales entre mercaderes y comerciantes. Y en ese caso, afirma Vitoria en la introducción a De Indis, se debe someter a deliberación y consulta de los prelados, predicadores o confesores, peritos de la ley divina y la humana, toda aquella materia sobre la cual el afectado u otros alberguen duda sobre su licitud con el fin de tener seguridad en conciencia.

Así por ejemplo, los dictámenes de 1507 y 1530 de algunos doctores de la Universidad de París en respuesta a las dudas de mercaderes de Flandes ${ }^{24}$, o la petición del negociante Angelo Brunengo a Tomás de Mercado para "poner en orden y estilo claro muchas decisiones de casos tocantes a mercaderes" ${ }^{25}$. Se trataba de averiguar, en cada circunstancia concreta, cómo debe conducirse el mercader, el cambista o el banquero, así como, en lo posible, promover un obrar virtuoso. El razonamiento escolástico combina la aplicación de principios generales que determinan lo lícito con el análisis de lo contingente, del "caso", lo cual trae consigo una importante labor de análisis. Se trata, en definitiva, de una investigación moral - de razón práctica - coherente con la labor pastoral de la Iglesia que busca responder en todo tiempo y lugar a las circunstancias nuevas que surgen en la historia desde una concepción antropológica intemporal e integradora del actuar humano.

El análisis económico escolástico no presupone un orden económico more geometrico al modo de la actual teoría económica neoclásica, sino que su objeto de estudio lo constituye, podríamos denominar, "lo justo económico"

23 Font, C. (2006, 2010).

24 Véanse en Zorroza, M. I. (2006), pp. 271-299.

25 Lagares, M. J. (2016). 
como investigación sobre lo justo localizado en un determinado espacio de sociabilidad, que es el relativo a los intercambios mercantiles y monetarios. La síntesis teológica tomista armoniza la fe con la tradición especulativa del aristotelismo en torno a la justicia, la práctica jurídica medieval de inspiración romana ${ }^{26}$ y una concepción de la ley resultado de la composición de cuatro tipos de legalidad (ley eterna, ley divina, ley natural y ley positiva) cuyo conocimiento sirve de fundamento de la ordenación política, jurídica y económica ${ }^{27}$. La propia ley natural conjuga "cierta necesidad" (STh. I-II, c. 94, a. 4) con una gran capacidad de adaptación para afrontar la contingencia propia del actuar humano, como así lo demuestra la innovación vitoriana en torno al derecho de gentes. En manos de los doctores escolásticos demostró flexibilidad y suficiente potencia analítica como para comprender las nuevas realidades que entonces surgían. En los tratados De legibus y De iustitia et iure, aunque no en exclusiva $^{28}$, quedaron recogidos los fundamentos jurídicos del pensamiento escolástico. La búsqueda de lo justo (conmutativo, distributivo y político) informa tanto la ley humana como la acción de gobernantes y gobernados. Subordinado a este marco, en el ámbito económico se configura un orden basado en la empresarialidad y la economía de mercado - dicho en términos actuales - donde surgen preguntas en torno a la relación entre valor y precio (teoría del precio justo), el dinero y el crédito (naturaleza del interés y de la usura), el beneficio (teoría del lucro), la estabilidad fiscal y monetaria (im-

26 Carpintero, F. (2008).

27 Cendejas, J. L. (2017).

28 Así los llamados "manuales de confesores" en los que abunda la casuística y que no van dirigidos a un público académico. La relevancia de estos manuales residía en la necesidad de compatibilizar la fe con las nuevas realidades económicas y sociales, esto es, se trataba de elaborar una guía moral para los sectores sociales más directamente implicados en los procesos de transformación que estaban teniendo lugar como eran comerciantes, funcionarios de la Corona y clérigos. Esto llevó a Pierre Vilar a afirmar que "el manual del confesor se convierte en un libro de análisis económico" (Oro y moneda en la bistoria, p. 217). Un tercer tipo de tratados donde se abordan cuestiones de interés para la economía son los manuales de tratos, contratos, cambios, etc. como los de Tomás de Mercado (Tratos y contratos de mercaderes y tratantes, 1569), Francisco García (Tratado utilísimo y muy general de todos los contratos, 1583) o los citados antes en la nota a pie $\mathrm{n}^{\circ} 5$.

29 Así por ejemplo, afirma Vitoria que "los bienes del rey son bienes públicos y de la república; y así cuanto el rey tuviere más bienes por una parte, si es justo príncipe, descargará a los vasallos de otros tributos y cargas", carta de Francisco de Vitoria a Miguel de Arcos de 28 de abril de 1546 (en Zorroza, 2006, p. 267). 
puestos justos ${ }^{29}$ y moneda sana) y el ejercicio y sentido de la limosna y los remedios de la pobreza ${ }^{30}$.

Para Vitoria, la justicia se diferencia de las demás virtudes en que consiste en una relación respecto a otro, y no a uno mismo como sucede, por ejemplo, con la templanza o la fortaleza (coment. a $S T$ S II-II, c. 57 , a. 1 y a la c. 58, a. 1). Lo justo es lo igual, y lo igual es siempre con respecto a otro. Como virtud debe hacerse conscientemente y por libre decisión, con firmeza y por su propia finalidad (coment. a STh II-II, c. 58, a. 1 y a. 2). La definición del Aquinate de la justicia ("El hábito según el cual uno, con constante y perpetua voluntad, da a cada uno su derecho", STh II-II, c. 58, a. 1) es óptima y universal e incluye los tres términos que considera Buridán: vivir honestamente, no hacer daño a nadie y dar a cada uno lo suyo ${ }^{31}$. Si se da a cada uno lo suyo se vive honestamente y no se le hace injusticia a nadie. La justicia se extiende a "conseguir la igualdad en orden a otro", aunque el derecho sea también en orden a uno mismo. Pagar la pena está incluido en "dar a cada uno su derecho", bien a la persona injuriada, a la comunidad o también a quien cometió la injusticia.

La justicia atiende a lo que es debido, y lo debido busca preservar una igualdad que para serlo, prescinde de la condición de los agentes (coment. a STb II-II, c. 57, a. 1). Por ejemplo, es indiferente que el que compra sea rico o pobre con tal de que dé lo equivalente. Propiamente, el derecho es lo justo (ius) y lo justo es el objeto de la justicia (iustitia): como consecuencia de que opera la justicia resulta algo que es justo. El derecho no es la ley. Ésta última es más bien una regla a la que ajustarse, es cierta razón o causa del derecho. Cuando los juristas afirman que la justicia es "una firme y constante voluntad de dar a cada uno su derecho" resulta claro que no se está tomando el derecho como si fuera lo mismo que la ley.

30 En la "controversia sobre los pobres" (Martín, V., 1999), el humanista Luis Vives (De subventione pauperum, 1526) defendía la supresión de la mendicidad eliminando la "caridad ciega indiscreta" e imponiendo el trabajo obligatorio: solo aquellos incapaces para trabajar debían recibir una asistencia de tipo público. Por su parte, Domingo de Soto (Deliberación en la causa de los pobres, 1545) defendía el derecho de los pobres a residir y a pedir donde estimasen oportuno en oposición a las diversas disposiciones de los ayuntamientos que lo restringían. Por su parte, Juan de Medina (De la orden que en algunos pueblos de España se ha puesto en la limosna para remedio de los verdaderos pobres, 1545) insistió en la regulación de la limosna.

31 Ambas definiciones en Ulpiano: "Iustitia est constans et perpetua voluntas ius suum cuique tribuendi" (Digesta $1.1 .10 \mathrm{pr})$ y "Iuris praecepta sunt haec: boneste vivere, alterum non laedere, suum cuique tribuere" (Digesta 1.1.10.1). 
Contrariando a Buridán (coment. a STb II-II, c. 58, a. 6), afirma Vitoria que no toda virtud es suficiente para orientar las obras a un buen fin y al bien común, aunque esto pueda suceder accidentalmente, sino que son la justicia o la caridad las virtudes que dirigen los actos hacia el bien común o hacia Dios, respectivamente. Se necesita una virtud especial para la conservación del bien público y esta es la justicia, porque es difícil obrar bien en lo referido al cumplimiento de las leyes. La justicia es la virtud más perfecta entre las virtudes morales puesto que se ordena a la gobernación y conservación del reino e incluye "actos muy perfectos" como impedir la guerra o la sedición y conseguir la igualdad (coment. a STh II-II, c. 58, a. 12).

Tomás de Aquino diferencia lo justo, que simplemente hablando, se halla "entre dos en absoluto distintos y no simplemente uno", de lo que sucede cuando uno es parte de otro: en sentido estricto ahí no cabe hablar de lo justo, sino de lo justo dominativo, bien paterno o bien doméstico (coment. a STh IIII, c. 57, a. 4). Para el Aquinate y para Vitoria, el derecho, lo justo en términos absolutos, se dice en relación a otro que es igual, por ejemplo entre dos hombres en que ninguno está sometido a otro, sino ambos al mismo príncipe (también para Aristóteles en Ética V, 6, 1134b: para hablar de injusticia se ha de atender a las leyes dadas por el príncipe). Pero el otro puede ser algo del primero, por ejemplo, el hijo es algo del padre o el siervo del señor. Así, cuando un padre maltrata a un hijo o un amo a un siervo, no cabe hablar de injusticia sino de impiedad, crueldad o ingratitud. Entre varón y esposa hay mayor derecho que entre padre e hijo o amo y siervo, aunque tampoco se da lo justo y la injusticia absolutamente, sino relativamente bajo algún aspecto. Como no hay ley que diga nada sobre las tres relaciones citadas (padre e hijo, amo y siervo, varón y esposa) no cabe hablar de lo justo en los mismos términos absolutos que cuando se habla de lo justo entre distintos que no son uno.

\section{DERECHO Y PROPIEDAD}

La relación entre el derecho natural y el derecho positivo resulta fundamental para entender la naturaleza de la propiedad particular (i. e. privada) desde la perspectiva del pensamiento escolástico. La propiedad particular es lícita por derecho positivo, aunque también lo es la propiedad común. Afirma Vitoria que "justo natural" se dice de aquello que es igual por su propia naturaleza, así devolver lo mismo que se ha recibido en depósito. Justo positivo y humano es lo determinado por un "pacto público", y a esto se llama ley, o también por un pacto privado (coment. a STh II-II, c. 57, a. 2). El derecho natu- 
ral también se denomina necesario por no depender de la voluntad humana: para que algo sea necesario basta con que la naturaleza no pueda disponer lo contrario, aunque la autoridad divina pudiera disponer otra cosa. Nada es de derecho natural si no se puede conocer naturalmente. Recuerda Vitoria que Tomás de Aquino afirma que son derecho natural las cosas que pueden ser conocidas por todos, salvo obstáculos como una mala costumbre, alguna depravada inclinación o una mala enseñanza o estudio.

El derecho natural por su naturaleza es medido en relación a otro. Se puede entender en sí mismo porque afirma cierta igualdad y justicia como "devolver lo prestado", o "no hagas a otro lo que no quieras que te hagan a ti". Por el contrario, el derecho de gentes se entiende como algo que es adecuado a otro en orden a otra cosa, como la división de las posesiones ${ }^{32}$ que no se refiere directamente a la igualdad y la justicia sino que se ordena a la paz entre los hombres ${ }^{33}$ (coment. a STh II-II, c. 57, a. 3). El derecho de gentes conlleva la equidad en relación a alguna otra cosa, no es equitativo por sí mismo, sino por un estatuto humano fijado racionalmente. Corrobora Vitoria la clasificación de Tomás de Aquino: el derecho natural en un bien por sí mismo, el de gentes no tiene en sí equidad, sino que está sancionado por un consenso de los hombres, es por tanto derecho positivo. Por ello los teólogos mencionan, correctamente, como ejemplos de derecho de gentes la propiedad particular de los bienes, la servidumbre, las manumisiones o la conservación del reino.

32 Para Tomás de Aquino, las cosas exteriores, en cuanto a su naturaleza, no están sometidas a la potestad humana, sino a la divina a la que obedecen todos los seres. Pero en cuanto a su uso, el hombre puede usar de ellas dado que los seres imperfectos existen por los más perfectos, siendo su dominio, por tanto, natural. El dominio le compete al hombre debido a su razón, en la que reside la imagen de Dios (STh II-II, c. 66, a. 1). Por desviarnos del objeto de este trabajo, no consideramos aquí el comentario de Vitoria a la c. 62 sobre la restitución donde desarrolla extensamente el origen y significado del dominio y su relación con el concepto de derecho. Sobre esto, pueden verse Brufau Prats, J. (1957), Cruz, J. (2008, 2017), González Fabre, R. (1998) y Zorroza, M. I. (2011, 2016).

33 Para Tomás de Aquino, es lícito que el hombre posea cosas propias (STh II-II, c. 66, a. 2) debido a tres razones: i) cada uno es más solicito en lo propio que en lo común que, huyendo del trabajo, se termina delegando en otros; ii) se administra de modo más ordenado que al tener que ocuparse de todo indistintamente reinando entonces la confusión; iii) y porque se mantiene el estado de paz entre los hombres si cada uno está contento con lo suyo: en aquello que es común suelen suscitarse contiendas con más frecuencia. Este uso no implica que se tengan las cosas exteriores como propias sino como comunes, de modo que se dé fácilmente participación de estas en las necesidades de los demás. De ahí que, si alguien se apropia de algo que era común en el comienzo, no debe privar de su uso a los demás (STb II-II, c. 66, a. 2, respuesta a la $2^{\text {a }}$ objeción). La distinción de las posesiones no es de derecho natural, sino positivo, pero ello no implica que el derecho natural se oponga a la propiedad particular. La propiedad es un desarrollo del derecho natural hecho por la razón humana por conveniencia debido a las razones expuestas (STh II-II, c. 66, a. 2, respuesta a la $1^{\text {a }}$ objeción). Una sociedad donde predominara el hurto sería inviable. Con el hurto se infiere perjuicio al prójimo en sus bienes. Como contrario, entonces, a la caridad es pecado moral (STh II-II, c. 66, a. 6). 
El derecho de gentes no se deduce necesariamente del natural, pues sería entonces también derecho natural. Sin embargo resulta casi necesario para la conservación del natural. Por ejemplo, podría subsistir un mundo sin propiedad particular, como así rige en las órdenes religiosas, pero habría discordias y guerras. Que el derecho de gentes no sea natural ni necesario, sino positivo, no implica que pueda abolirse igual que el resto del derecho positivo: cuando por acuerdo de todo el orbe se admite algo, para su derogación sería preciso idéntico acuerdo, pero resulta imposible que todo el orbe se ponga de acuerdo para la abolición del derecho de gentes.

Por derecho de gentes, las cosas sin dueño, como tesoros y minas, son del primer ocupante o del que las encuentra. Sólo si esto no conviene a la república, pueden dividirse entre los que forman parte de ella (coment. a STh II-II, c. 66, a. 1). Es lícito para los cristianos tener bienes propios (coment a STh II-II, c. 66, a. 2). De otro modo no se entendería la obligación de la limosna, pues de lo que es común no puede darse limosna. La comunidad de la que se habla en los Hechos de los Apóstoles, además de voluntaria, fue de duración desconocida. El hecho de que se hicieran colectas para los pobres muestra que en ella había cosas que no eran comunes. La comunidad de bienes requiere muchas cosas que no suelen hallarse en la sociedad: modestia, concordia, debida sujeción, justa distribución, que a duras penas se dan entre los religiosos. Bajo un régimen de comunidad de bienes, el avaro y el ladrón se llevarían más cosas que el "buen varón".

Como afirma Tomás de Aquino, la división de las cosas no se ha realizado por el derecho natural, aunque este no la prohíbe. Escoto afirma que por derecho natural todo es común, pero que tal derecho ha sido revocado. Esto lo rebate Vitoria afirmando que jamás sucedió que todo fuera común ni consta ninguna dispensa ni revocación pues no existe precepto que dispensar o revocar. El derecho natural sigue vigente, pero lo que pudo convenir en el estado de inocencia, dejó de hacerlo tras la Caída. La división de los bienes a partir de la propiedad común lo es por derecho de gentes. Este, como se ha visto más arriba, participa tanto del natural como del positivo, aunque sobre todo de este último, y por esta razón, puede cambiar.

La vigencia del derecho natural en lo que a la propiedad común se refiere, la expone Vitoria al afirmar la licitud del robo en caso de grave y extrema necesidad (coment. a STb II-II, c. 66, a. 7). Sin embargo, han de concurrir circunstancias excepcionales que la limitan sobremanera: además de la extrema necesidad, el propio pobre debe actuar como juez y determinar que su pobreza es mayor que la de otros, así como juzgar sobre si los bienes del rico son su- 
perfluos $^{34}$. El rico está obligado a dar al pobre por caridad, pero no por justicia, por lo que del rico no puede tomarse por la fuerza. La situación de extrema necesidad se da antes de llegar al "último aliento de vida". Basta con que el indigente esté "yaciente", angustiado por sus dolencias, hambriento o con familia a la que no pueda mantener. Entonces el robo a los ricos es lícito si se puede hacer sin escándalo.

\section{JUSTICIA CONMUTATIVA E INTERCAMBIO}

Divide Aristóteles la justicia en particular y general - o justicia política -. Dentro de la primera, la justicia correctiva, o conmutativa, se refiere a las relaciones entre los miembros de la polis en tanto iguales. Como consecuencia de los diversos tratos (voluntarios o involuntarios) debe quedar preservada dicha igualdad. Dentro también de la justicia particular, la justicia distributiva se refiere a lo que la polis debe a sus miembros proporcionalmente en tanto contribuyen de modo distinto al bien de la polis, por ejemplo, mediante el reconocimiento de méritos u honores. Un tipo especial de relación entre los miembros de la polis es la reciprocidad. Las acciones recíprocamente proporcionadas mantienen unida a la polis. Dentro de la reciprocidad se incluye el intercambio en el cual la mediación del dinero permite igualar desiguales a través de la necesidad. El dinero, medida convencional establecida en virtud de un acuerdo, resuelve el problema de la conmensurabilidad, necesaria para dicha igualación, al menos en grado suficiente como para actuar a manera de sustituto de la necesidad ${ }^{35}$.

Como discípulo del Aquinate, Vitoria suscribe la división aristotélica de la justicia. La justicia es conmutativa si pone orden entre dos personas privadas, por ejemplo, si pone igualdad entre quien compra y quien vende (coment. a STh II-II, c. 61, a. 1). Y es distributiva si pone igualdad entre la república o

34 Afirma Tomás de Aquino que, conforme a la ordenación de las cosas exteriores a la satisfacción de las necesidades de los hombres, que es de derecho natural, la apropiación, que se realiza por derecho positivo, no ha de impedir que se atienda a la necesidad del hombre. Así que, si la necesidad es evidente y urgente, es lícito sustraer las cosas ajenas, de modo manifiesto u oculto, y no puede considerarse a esto hurto o rapiña (STh II-II, c. 66, a. 7). Se deja al arbitrio de cada uno la distribución de las cosas propias para socorrer a los que padecen necesidad dado que son muchos y no se puede socorrer a todos con la misma cosa, aunque los bienes superfluos son debidos por derecho natural al sostenimiento de los pobres. En la c. 32 de la II-II sobre la caridad aborda Tomás de Aquino su concepción de "lo necesario" y "lo superfluo".

35 Aristóteles, Ética V, 5, 1133a 15-30. 
comunidad y una persona privada. Coincidiendo con Cayetano ${ }^{36}$, hay tres especies de justicia: si se compara el todo con el todo se habla de justicia legal (como el súbdito con el rey), de conmutativa si es la parte con la parte, y de distributiva si es el todo con las partes. Aunque la deuda pertenezca a la justicia conmutativa y a la distributiva, mayor deuda hay en la conmutativa, por lo que si se yerra en esta, se hace mayor injusticia. El justo medio en la justicia conmutativa se determina por la proporción aritmética guardando la proporción de la cosa a la cosa, mientras que en la distributiva se atiende a la proporción de la cosa a la persona (coment. a STh II-II, c. 61, a. 2).

Se pregunta Vitoria si justo es lo mismo que contrapassum (esto es, la ley del talión, o como se dijo más arriba "reciprocidad"). En el intercambio parece darse ${ }^{37}$ pues se recibe tanto como se dio, pertenece por ello a la justicia conmutativa (coment. a STh II-II, c. 61, a. 4). Los tratos que recaen bajo el ámbito de la justicia conmutativa pueden ser voluntarios (compraventa, préstamo, fianza, usufructo, depósito, alquiler) o involuntarios. Estos últimos son fundamentalmente delitos que exigen un castigo o reparación que restituya de algún modo la igualdad previa a su comisión. Vitoria, comentando a Tomás de Aquino, considera de la compraventa (c. 77 de la II-II) las circunstancias que podrían hacerla fraudulenta pudiendo considerarse en ese caso como hurto o rapiña ${ }^{38}$. Son cuatro los aspectos tratados: (i) la venta injusta por razón del precio (que podríamos denominar "teoría del precio justo"), (ii) la injusticia por razón de la cosa vendida, (iii) la obligación de manifestar los vicios de la cosa vendida, y (iv) el aumento del precio en el comercio respecto al coste de adquisición de la cosa (que podría entenderse como una "teoría del lucro" o del beneficio empresarial).

De acuerdo con Schumpeter ${ }^{39}$, el hecho de que la cuestión 77 sea sobre el fraude revela que Tomás de Aquino entiende por precio justo el de un mercado competitivo normal, aunque no lo aclare explícitamente ya que esto se daba por sobreentendido entre los juristas: si el mercado es competitivo difí-

36 Tomás de Vío, cardenal Cayetano (1468-1534), dominico, quien también comentó la Suma de Tomás de Aquino.

37 Aristóteles, Ética V, 5, 1133a.

38 La distinción entre hurto y rapiña se basa en el hecho de que el primero implica una apropiación oculta de lo ajeno, con ignorancia por parte del que es hurtado, y la rapiña, una apropiación realizada de modo manifiesto y mediando violencia (STh II-II, c. 66, a. 4). Hurto y rapiña comparten el hecho de ser involuntarias para el damnificado, bien por ignorancia el primero, o por mediar la violencia en la segunda. La rapiña redunda además en cierta injuria a la persona.

39 History of Economic Analysis, p. 93, nota a pie n ${ }^{\circ} 15$. 
cilmente los vendedores pueden imponer un precio por encima del vigente, lo que sí pueden hacer entonces es engañar con la cantidad y/o la calidad que es de lo que trata esta cuestión. Y en efecto, como se ve a continuación, tanto para Tomás de Aquino como para Vitoria, una compraventa injusta es consecuencia del fraude, del engaño o de la necesidad. Esta última resulta, aunque no solo, de la existencia de poder de mercado en forma de monopolio o monopsonio ${ }^{40}$.

1. Teoría del precio justo: la venta injusta por razón del precio (STb II-II, c. 77, a. 1)

Comenzando por el análisis que realiza Tomás de Aquino, a la primera cuestión (STb II-II, c. 77, a. 1), esto es, si es lícito vender una cosa más cara de lo que vale, la respuesta es tajante: vender por encima del precio justo es pecado al engañar al prójimo en su perjuicio. También lo es que el vendedor ponga un postor que eleve el precio, o el comprador otro que puje a la baja (citando a Tulio). Esto es, es ilícito cualquier tipo de fraude que altere el precio. Excluido el fraude y en su esencia, la compraventa parece instituida en interés de ambas partes por necesidad mutua. Por ello no debe redundar más en perjuicio del uno que del otro debiendo el contrato basarse en la igualdad de la cosa. El valor se fija en términos monetarios, de ahí que se deba atender a si el precio excede o no cubre el valor de la cosa, lo que sería injusto. Por lo tanto, de este análisis del Aquinate, y una vez excluido el fraude, el problema radica en determinar el precio justo, esto es, aquel que iguala el valor de la cosa.

Además de a su esencia, es preciso atender a las circunstancias que, accidentalmente, podrían hacer injusta una compraventa debido a que una de las partes recibiera utilidad y la otra perjuicio. Esto sucede cuando alguien tiene gran necesidad de la cosa de la que se va a desprender o bien va a recibir un gran provecho de la que desea adquirir. En caso de perjuicio del vendedor por desprenderse de la cosa, el precio podrá ser mayor al valor de la cosa - a manera de indemnización -, aunque no superior al valor que tiene para él. Sin embargo, si es el comprador el que obtiene un gran provecho sin perjuicio del vendedor, no se justifica un precio mayor al valor de la cosa, ya que el vende-

40 Estos son términos actuales que no utiliza Vitoria. Sí se refiere Vitoria en ocasiones a la presencia de un monipodio cuyo significado, según la RAE, es un "convenio de personas que se asocian y confabulan para fines ilícitos". 
dor no puede cobrar por algo que no le pertenece, esto es, el provecho que recibe el comprador como consecuencia de sus propias circunstancias ${ }^{41}$. Si bien, por honradez, el comprador podría dar al vendedor espontáneamente algo más.

No incide Tomás de Aquino en la relación entre el grado de concurrencia en el mercado, la formación del precio y su carácter de justo, esto es, en las condiciones que permitirían la igualación del precio con el valor de la cosa. Cuestión sobre la que sí se va extender Vitoria al considerar las circunstancias que impiden que se llegue a la "común estimación" propia del precio justo. Al comentar la cuestión de la justicia (coment. a STh II-II, c. 58, a. 3), Vitoria ya anticipó que la justicia era la virtud que versaba principalmente sobre los intercambios entre los hombres, lo que incluía el comercio. Entonces, se pregunta, ¿por qué no se alaba a los comerciantes que hacen actos de virtud comprando y vendiendo con justicia? El comercio es un oficio peligroso porque es difícil quedarse en el justo medio, pero "si los comerciantes hacen bien su oficio, sus actos son virtuosos y dignos de alabanza". Esta afirmación resume el espíritu de Vitoria al abordar la actividad mercantil, que supera en cierta medida la "cierta torpeza" que encierra el comercio en la perspectiva del Aquinate (STh II-II, c. 77, a. 4).

Vitoria comienza su comentario a la c. 77 con un breve resumen de ésta destacando la diferencia fundamental entre lo que es la compraventa en su esencia, sin mediar fraude o engaño, en la que el precio debe igualar al valor de la cosa, y lo que pueda suceder accidentalmente, y es que pueda no darse esta igualdad. Al quedar perfectamente establecido que el precio justo es aquel que iguala al valor de la cosa, el núcleo de la cuestión reside entonces en cuál sea el valor de la cosa. Al ser diversas las cosas que se intercambian, una de ellas habitualmente dinero ${ }^{42}$, las naturalezas, que son distintas, no pueden igualarse, sino que es mediante el precio como se determina la común estimación de los hombres (recuérdese lo dicho por Aristóteles) o mediante un

41 En términos actuales, podríamos decir que no es lícito apropiarse del "excedente del consumidor", la práctica que la teoría económica denomina "discriminación de precios", y que solo es posible cuando hay poder de mercado.

42 Posteriormente, Luis de Molina profundizará en la distinta naturaleza del intercambio que se realiza mediante trueque o mediante dinero. Estrictamente, el precio y la mercancía surgen simultáneamente cuando el intercambio es monetario. Ello produce además una asimetría entre comprador y vendedor y sus actos respectivos que no existe en el trueque. La naturaleza de la compraventa es distinta y en ese contexto surgen las preguntas sobre el precio justo en dinero y el doble aspecto del dinero: como precio y medida fija - dinero legal - o como mercancía con un determinado valor intrínseco. Véase Gómez Camacho, F. (1981), pp. 27-29. 
acuerdo. Y esto se aplica al propio dinero cuya naturaleza no consiste en tener siempre el mismo valor, sino que éste también se ve afectado por la estimación humana: "no es preciso considerar si esto es oro y lo otro plata, sino la estimación de los hombres". Vitoria no llega a extraer todas las consecuencias analíticas de esta afirmación sobre el valor del dinero, algo que sí harán otros miembros de la Escuela de Salamanca, como Azpilcueta, Domingo de Soto, Tomás de Mercado o Juan de Mariana.

Debido a que el origen del valor es la común estimación, donde hay muchos compradores y vendedores no es preciso preocuparse por las diferencias en el precio que se producen desde que se compra y hasta que se vende una determinada mercadería. Son indiferentes los trabajos o peligros que hayan podido mediar en la adquisición: si ha habido un cambio en la común estimación, está justificado que haya diferencias en el precio de lo que se compra en relación a cómo se vende. El justo precio es "a como vale en la plaza" y es a lo que debe atenderse. Las quince consideraciones de Conrado $^{43}$ (De contractibus, tract. III, q. 56) sobre el precio justo y el justo valor de la cosa sirven antes de que el precio se haya establecido por la común estimación, pero no en su lugar.

El modo de vender la cosa influye en el precio. Por ejemplo, es lógico que el precio sea distinto de comprar o vender por grueso o por menudo, mientras no haya fraude o engaño y así sea la común estimación. Si no hay muchos compradores y vendedores, el precio de la cosa no puede fijarse por la común estimación y sí deben tenerse en cuenta entonces las consideraciones de Conrado. En ese caso, es preciso atender a los gastos, el trabajo, el peligro y la escasez, que elevan el precio de la cosa y conforme a eso el vendedor puede establecer un precio razonable.

En caso de haber muchos vendedores y uno o pocos compradores, no debe atenderse tampoco a la común estimación, sino a las causas razonables según el "arbitrio de un varón honesto" ${ }^{4}$. No es lícito que si hay un solo comprador, éste se aproveche de la necesidad que tiene alguien de vender. Por el contrario, si hay varios compradores, el precio que resulte es el de común es-

43 Conrado de Summenhart (1450/60-1502), dominico, autor de Opus septipartitum de contractibus en el año 1500.

44 Esta justificación del precio justo, bien resultado de la común estimación si se dan las condiciones descritas, o, en su ausencia, el criterio de un "varón honesto", impide identificar sin más el precio justo con el precio de mercado, y por extensión, impide considerar la teoría del precio justo como comprendida en la teoría del precio de equilibrio. Estamos ante dos paradigmas científicos, el escolástico y el neoclásico, que presentan los habituales problemas de incomparabilidad entre mundos teóricos (véase Gómez Camacho, F., 1981, pp. 34-37). 
timación y por lo tanto es lícito. Los acuerdos de colusión que conducen a la formación de un monopolio o de un monopsonio implican fraude y obligan a restituir. Aquí se incluye el hecho de acaparar comprando todo el trigo (en el ejemplo aducido) para luego venderlo más caro. Respecto al precio que resulta de la común estimación, el precio legal goza de prioridad ya que obliga en conciencia y es el precio justo ${ }^{45}$, salvo lo indicado más adelante respecto a sus límites.

Respecto a vender en lo máximo que se pueda ("res tantum valet quantum vendi potest") sin mediar fraude, engaño o ignorancia debe atenderse a si la cosa es necesaria, esto es, a si se trata de bienes de primera necesidad dicho en términos actuales. Cuando hay muchos vendedores es lícito hacerlo según el precio establecido y común. No en cambio si hay pocos vendedores. En las cosas que sirven de adorno o curiosidad, es lícito vender a cuanto se pueda si hay plena voluntariedad, no así si concurre necesidad o violencia. Pero, en ausencia de éstas, se puede vender a cuanto se pueda, porque al que consiente no se le hace injuria ("volenti non fit iniuria"): igual que no se está obligado a restituir cuando se recibe una donación, tampoco se está en caso de recibir más de lo que vale la cosa, siempre que no medie engaño, ignorancia, necesidad o temor, esto es, siempre que haya plena voluntariedad.

Respecto a si se está obligado a restituir si se vende o se compra en más o en menos de la mitad del precio justo ${ }^{46}$, Vitoria señala la posibilidad de que

45 En la Carta a Miguel Arcos de 28 de abril de 1546, recuerda Vitoria a propósito del precio del trigo (STh II-II, c. 77, a. 2): "es doble el precio justo de la cosa; a saber, o bien el instituido por la ley o bien el instituido por la costumbre". En la misma carta, Vitoria muestra cómo funciona el mercado por naturaleza: "Y ex natura rei es necesario que sea así: que yéndose apocando el trigo y los vendedores, y creciendo las necesidades, ha de crecer el precio" (Zorroza, M. I., 2006, p. 266). Donde hay muchos vendedores, "el precio se hace de suyo", de ahí que quien suba el precio en primer lugar cuando se produce una escasez generalizada resulta algo accidental. Otra cosa distinta es que, en esas circunstancias de carestía general, los vendedores deban procurar mantener la ganancia moderada y "no hagan cuanto mal pueden a los pobres", esto es, no han de vender el trigo "a cuanto se pueda" (i. e. apropiarse del excedente del consumidor).

46 Para Tomás de Aquino, el hecho de que el precio se determine por leyes civiles no hace lícito que compradores y vendedores procuren "engañarse recíprocamente" (STh II-II, c. 77, a. 1, respuesta a la $1^{\mathrm{a}}$ objeción). Las leyes humanas se dan al pueblo, donde se mezclan muchos carentes de virtud con virtuosos y aquellas no pueden prohibir todo lo contrario a la virtud, solo lo que destruye la convivencia social. Lo no prohibido es lícito, pero no porque se apruebe, sino porque no se castiga. Así, excluido el fraude, compradores y vendedores pueden vender y comprar en más o en menos de lo que vale la cosa mientras la diferencia no sea excesiva. Una diferencia se considera excesiva, conforme a la ley humana (Codex Iustinianus, 4.44.2), cuando el precio excede, en más o en menos, la mitad del precio justo. En ese caso, existe obligación de restituir. Sucede que el precio justo no está exactamente determinado, sino que se fija mediante una "estimación aproximada" que no destruye la igualdad que la justicia requiere. 
las leyes humanas, el rey o el juez, puedan determinar que ello es lícito y, por lo tanto, no se estaría obligado a restituir. Sin embargo, Vitoria afirma que realmente no lo es y se está obligado a restituir, y si alguna ley lo autorizara sería inicua y peligrosa. Esto es, el precio fijado por ley humana puede ser injusto si se aparta del margen mencionado. En este proceder se incluye la fijación de los honorarios del médico o del abogado. También el señor que paga a su siervo menos de la mitad de su justo salario está obligado a restituir aunque el siervo lo acepte, puesto que pudo haber necesidad y, por lo tanto, el consentimiento no fue plenamente voluntario. Por último, del hecho de que el precio justo no consista en un único valor, sino que tenga extensión, esto es, que el precio justo sea una estimación aproximada, como así lo afirma también Tomás de Aquino, concluye Vitoria que, dentro de ese margen, cabe pedir algo más si se vende al fiado sin que esto constituya usura.

2. Obligación de manifestar los vicios de la cosa vendida (STb II-II, c. 77, a. 3)

Aclara Vitoria que este artículo trata del vicio de la cosa, que no debe confundirse con el defecto, que era de lo que trataba el artículo anterior ${ }^{47}$. Todo vicio de la cosa es un defecto, pero no al contrario. Por causa de defecto, la venta se convierte en injusta, pero por causa de vicio, no tiene por qué serlo siempre que el precio sea justo, esto es, cumpla con lo señalado en el artículo primero. Se trata entonces de juzgar sobre la obligación que tiene el vendedor de informar sobre ello.

La diferencia entre vicio manifiesto y oculto es fundamental. Si el vicio es oculto, siempre que no medie peligro o daño para el comprador, y el precio sea el justo, esto es, rebajado teniendo en cuenta ese vicio, se pregunta Vitoria si el vendedor está obligado a informar, pues es posible que el comprador, de haberlo sabido, no hubiera accedido a la compra. La venta podría ser nula pues ha habido ignorancia, y mediando ignorancia, el acto no es voluntario. Vitoria coincide con Cayetano y con Tomás de Aquino afirmando que la venta es lícita si se dan las condiciones recién señaladas. Pone el ejemplo de la validez del matrimonio en algunos casos en que hay ocultación o cierto vicio en

47 Respecto al artículo 2 de la c. 77, sobre la injusticia por razón de la cosa vendida, Vitoria resume lo dicho por Tomás de Aquino: cuando hay un defecto en la cosa vendida con conocimiento del vendedor, la venta es injusta y da derecho a la restitución, sea aquel defecto en la naturaleza, la cantidad o la calidad de la cosa. Si el vendedor lo ignora no incurre en pecado porque su acción en sí no es injusta. Pero cuando tuviera conocimiento de ello estaría obligado a restituir. Lo mismo sería de aplicación para un comprador que compra por menor valor de lo que vale la cosa sin conocimiento del vendedor. 
uno de los contrayentes: con más motivo sería válida una compraventa, que es un contrato de menor relevancia.

Si el vicio es manifiesto, pero ignorado para el comprador, y la venta es válida, también cuando lo sea oculto, pues equivale de hecho a lo primero. La ignorancia no invalida la venta, que es fundamentalmente voluntaria, aunque haya mezcla de lo involuntario. Si el vendedor calla sobre un vicio oculto, no peca, siempre que el precio esté ajustado, pero si el vendedor es interrogado sobre un vicio oculto y miente, sí peca y está obligado a la restitución. En definitiva, el vendedor no está obligado a suplir la diligencia del comprador.

Respecto al conocimiento que tenga el vendedor sobre una bajada futura del precio por una mayor afluencia de, por ejemplo, trigo, no le obliga a éste ni a bajar el precio, mientras se ajuste a la estimación común en el momento presente, ni a revelarla. $\mathrm{Y}$ en caso contrario, si un comprador, en virtud de su arte, tiene conocimiento de un aumento futuro del precio de cierta mercaduría (de nuevo, trigo en el ejemplo), no está obligado a revelárselo a aquel a quien se la compra hoy más barata ni a restituirle mañana cuando el precio haya subido. Es decir, es lícito comprar barato hoy y vender más caro mañana, si ambos precios se basan en la común estimación de dichos momentos y respetan lo dicho sobre el precio justo.

3. Teoría del lucro: el aumento del precio en el comercio respecto al precio al que se compró (STh II-II, c. 77, a. 4)

Merece la pena exponer aquí la doctrina de Tomás de Aquino sobre el comercio y el precio justo para apreciar el avance de Vitoria, aunque siempre dentro de los límites fijados por el maestro. El comercio en sí no es ilícito, los vicios del comercio lo son del hombre y no del arte en sí, afirma el Aquinate citando a San Agustín (STb II-II, c. 77, a. 4). Repite Tomás de Aquino los argumentos de Aristóteles en torno al comercio, no obstante se aparta en un punto fundamental. El intercambio puede ser natural - la crematística natural aristotélica -, bien mediante trueque o mediante dinero, cuando se produce para satisfacer las necesidades de la vida. Este comercio es propio de los cabezas de familia o de los jefes de la ciudad (los dos comunidades naturales: oikos y polis). Aun así, el comercio en sí mismo encerraría cierta torpeza. No obstante, si bien el comercio en su esencia carece de elemento honesto o necesario, tampoco hay en ella nada vicioso u opuesto a la virtud. El lucro puede estar ordenado a un fin necesario o incluso honesto y ser por ello lícito. Sucede cuando el "moderado lucro" se destina al sustento de la familia, a socorrer a los 
necesitados, o si el comercio sirve al interés público para proporcionar a la patria las cosas necesarias. En este caso, ya no se busca el lucro como fin, sino como remuneración del trabajo. En la respuesta a la primera objeción (STh II-II, c. 77, a. 4) afirma Tomás de Aquino que es lícito vender a un precio mayor por el que se adquirió la mercancía si se ha mejorado por el trabajo - en ese caso, el sobreprecio parecería el precio del trabajo - o bien si el lucro no se busca como un fin último sino en orden a otro fin necesario u honesto. En la respuesta a la segunda objeción, declara lícito vender más caro si no era esto lo que se buscaba, es decir, si quien se beneficia de, lo que calificaríamos hoy en día, como un incremento del valor patrimonial, lo hace como consecuencia de mejoras en la cosa, de variaciones del precio por diferencias de tiempo y lugar, o por el peligro al transportar de un lugar a otro. Esto es, la ilicitud reside en el hecho de que se compre para vender más caro sin añadir nada o sin que cambie ninguna circunstancia, siendo el lucro fin exclusivo y último.

A partir de este artículo, Vitoria expone una serie de dudas. Confirma Vitoria que el lucro, la búsqueda de riquezas como fin en sí mismo sin estar ordenado a un fin honesto, es torpe e ilícito. Negociar así es peligroso, se cae en la tentación y en el engaño (San Pablo, Primera Carta a Timoteo, 6: 9) y "difícilmente entrará un rico en el Reino de los Cielos" (Mateo 19: 23-24). Se trata, no obstante, de un pecado venial si no hay intención de hacer injuria a otros. No es pecado mortal pues la negociación no va contra la caridad de Dios, ni del prójimo, ni de ningún precepto especial. Podría ser pecado mortal si hay un deseo insaciable e infinito, pero no si se hace "atesorando para los hijos".

Respecto a los comerciantes que venden al por menor (los denominados recatones) sin modificar la mercancía, ni en tiempo ni en lugar, se pregunta Vitoria si es lícito que vendan más caro de lo que compraron. Lo es si hay cambio de lugar (transporte) pues, de otro modo, no podría atenderse a la necesidad de la república. También lo es si ha pasado el tiempo (almacenaje diríamos hoy), si ha habido transformación de una materia prima, o si se cambia el modo de vender: así si se compra por junto y se vende por menudo. Pero no es lícita la actividad de los recatones que compran la mercancía a quienes la llevan a la ciudad y la venden antes que ellos a un precio mayor y sin modificarla en nada. A estos hay que expulsarlos de la república y apartarlos de los negocios.

La negociación que no añade nada, y se aprovecha de comprar barato y vender más caro sin mediar ni siquiera el tiempo, y con el fin exclusivo de obtener un provecho es ilícita, concluye Vitoria tras repasar la opinión de distintas autoridades. Es factible actuar así porque el precio justo tiene extensión y con esta negociación se puede aprovechar ese intervalo para obtener cierta 
ganancia, pero esto no la hace justa pues perjudica al verdadero comprador, aquel que necesita la cosa, al elevar el precio ${ }^{48}$, y también al vendedor que obra de modo lícito. Aun siendo ilícita esta negociación, no es preciso restituir a quien compró en último lugar pues se supone que, en todo caso, el vendedor se ha movido dentro del margen permitido por el precio justo. El modo en que se realice esta operación determina que sea pecado mortal o solo venial. Si se trata de una compra por un solo comprador que, de este modo, acapara para luego vender más caro, éste peca mortalmente, e incluso, los que actúan así, deberían restituir a la misma república por el daño general que causan. Si la compra, con intención de reventa, es accidental, se peca venialmente si, al hacerlo, se impide que quien necesita la cosa pueda comprarla. Si esta reventa con ganancia se produce accidentalmente ${ }^{49}$, sin la intención de vender la cosa más cara, ni se peca ni hay obligación de restituir.

La compra (p. ej. de trigo) con intención de vender más adelante a un precio mayor es pecado grave y hay obligación de restituir. Tanto las leyes civiles como el derecho natural y divino así lo establecen. No supone contrargumento el hecho de que el beneficio que unos pocos obtienen permanezca en la república, pues no es lícito beneficiar a unos pocos a costa de muchos. Pero si quienes compran el trigo, lo almacenan debido a que los agricultores no pueden conservar todo el grano, se trata de un bien siempre que por este oficio la cosecha no se encarezca. La compra de trigo en primavera para su venta en mayo, cuando se encarece, es una negociación peligrosa pues induce a la avaricia. Si se espera un beneficio honesto, se acepta, pero en absoluto si se hace con mala intención deseando el mal de la república y para que el trigo se encarezca.

48 Estas operaciones, que podríamos denominar de arbitraje, reducen la extensión del intervalo de precios. En el límite, bajo arbitraje perfecto y ceteris paribus, el precio terminaría adoptando un único valor. Leído de otro modo, la "extensión del precio justo" es el resultado de las condiciones realmente existentes en el mercado, que permiten ciertas operaciones de arbitraje por parte de los recatones, y que Vitoria condena por no añadir nada.

49 Algo análogo se recoge en los casos quinto y sexto del Parecer sobre cambios y finanzas de los Doctores de París (1530), consulta de los mercaderes españoles de Amberes sobre cambios y respuesta de los doctores de París. Véase Zorroza, M. I. (2006), p. 296-297, en que se aprovecha la variación en el precio que se puede producir en el intervalo temporal que media entre la venta al fiado y el momento de saldar la operación. Sin serlo estrictamente, pues no hay en principio intención de ganar por el mero paso del tiempo, la apariencia es de usura. 
Vender más barato que otros es lícito siempre que no se haga con la intención de perjudicar a otros vendedores ${ }^{50}$, sino de buena fe. Es meritorio y de provecho para la república. Sobre a quién corresponde la ganancia cuando se negocia con dinero prestado, duda que le fue consultada a Vitoria en Flandes, si no se ha estipulado de otro modo y no se le retiene ese dinero a su dueño, gana quien ha negociado con él. Por último, si uno vende con ganancia por cuenta del dueño, esa ganancia corresponde al dueño, pues el vendedor (el corredor) seguramente ya recibe una remuneración por el servicio prestado.

\section{CONCLUSIONES}

Para Vitoria, de modo coherente con la perspectiva aristotélico-tomista en la que se inserta su pensamiento, la justicia es la virtud de la que depende la realización del bien en el seno de la comunidad política. De la práctica de la justicia se deriva la generación de un orden social que no procede de la violencia o de la coacción. Lo justo en los intercambios presupone actos libres para los que no basta un mero consentimiento por ambas partes, sino que han de darse las condiciones reales que permiten hablar de un acto plenamente voluntario. Este es el prerrequisito fundamental de una compraventa lícita. El intercambio entre iguales exige el intercambio de cosas equivalentes, y en esto consiste precisamente la justicia conmutativa. Discernir sobre lo justo de un intercambio es hacerlo sobre la plena voluntariedad de los actos de compra y de venta.

Su doctrina de la propiedad sigue la doctrina tomista. La propiedad particular es lícita por derecho de gentes - derecho positivo -, aunque también lo es la propiedad común. La propiedad particular es preferible a la común pues cumple mejor que esta con el fin al que está ordenada que es la paz entre los hombres. La comunidad de bienes presenta problemas de viabilidad debido al grado de exigencia moral que requiere. Mientras que Vitoria da más peso a las ventajas de la propiedad particular a la hora de favorecer la convivencia pacífica, Tomás de Aquino contemplaba también razones de eficiencia que Vitoria parece dar por asumidas o de orden secundario.

50 Podríamos entender que Vitoria se está refiriendo aquí a lo que hoy denominaríamos "guerra de precios" que busca exclusivamente desalojar al competidor y conseguir una situación de monopolio. 
El fraude y el engaño comportan ignorancia, mientras que se ejerce cierta violencia sobre el necesitado cuando el monopolista o el monopsonista se aprovechan de su necesidad. La presencia de involuntariedad en el intercambio debido a la ignorancia o a la violencia asemejaría la compraventa al hurto o a la rapiña, de ahí su condena ${ }^{51}$. En los actos de compraventa, el intercambio justo lo es a un precio que iguala el valor de la cosa con lo efectivamente pagado por ella. Dicho valor se conoce por la común estimación. En defecto de una común estimación, debe atenderse a las diversas circunstancias hasta llegar a dicho acto, esto es, a los gastos, el trabajo, el peligro o la escasez, es decir, es preciso atender a los costes de producción. De una concurrencia suficiente de compradores y vendedores que interactúan mediante actos voluntarios resulta una opinión sobre el valor de la cosa con la que todos concuerdan pues resulta precisamente de sus propios actos. El intercambio a un precio justo preserva la igualdad natural de la cosa con lo pagado por ella de modo que ni comprador ni vendedor sufren injusticia.

La igualdad entre precio y valor de la cosa es una igualdad posible, no exacta: dada la extensión del precio justo resultan lícitos los intercambios a precios dentro de un margen. Puesto que, en la operación real de un mercado, la información no se concentra en un único punto, no cabe esperar que todas las transacciones entre compradores y vendedores se realicen a idéntico precio. El hecho de quedar sometidos los agentes a una común estimación, no resta responsabilidad personal a sus decisiones. Así, por ejemplo, el precio aumenta si hay general carestía ex natura rei, pero ello no impide el ejercicio de una acción moralmente responsable (recuérdese lo dicho en la nota a pie ${ }^{\circ}$ 46). En ausencia de las condiciones de concurrencia que impiden disponer de una común estimación y que conceden poder de mercado a algún o a algunos agentes, el criterio justo es el que determinaría un "varón honesto", esto es, conforme a los principios consuetudinarios del derecho. En ese caso, el coste de producción proporcionaría una valoración justa. El precio legal goza de prioridad sobre el precio de mercado, aunque ha de ceñirse al margen determinado para el precio justo conforme a derecho.

51 A este respecto, conviene recordar que, para Tomás de Aquino, la violencia se opone más directamente a la voluntad que la ignorancia por lo que resulta más grave (STh II-II, c. 66, a. 9). En sociedad, nadie puede usar la coacción a no ser por "pública potestad" (STh II-II, c. 66, a. 8). A los príncipes corresponde guardar la justicia, así que el uso de la violencia o de la coacción ha de ser con arreglo a las exigencias de la justicia, por ejemplo, contra los enemigos o los malhechores, y si no es así, la autoridad pública está obligada a la restitución. 
En definitiva, el análisis económico de Vitoria, como muestra del pensamiento económico escolástico, sitúa la compraventa en el ámbito de los tratos voluntarios, por lo que debe ajustarse a la estricta equivalencia de lo intercambiado, constituyendo este un principio de derecho natural. La determinación de la equivalencia de cosas que, por su naturaleza, son distintas se resuelve conforme a una valoración factible fruto de una común estimación cuya característica fundamental es que procede de la concurrencia de iguales, de modo que el precio - intervalo de precios más bien - preserva la justicia. El lucro derivado de la actividad mercantil es lícito si concurren las razones expuestas por Tomás de Aquino: básicamente que sirva a la comunidad, familiar o política, que sea moderado, que la actividad mercantil "añada algo" y que el lucro no sea un fin en sí mismo; a las que Vitoria aporta una consideración importante que se podría sumar a las citadas. Su licitud también resulta del hecho de comprar y vender a precios justos fruto de la común estimación. Con ello quedarían integradas las teorías del precio justo y del lucro honesto bajo la común perspectiva de lo justo en los intercambios.

\section{BIBLIOGRAFÍA}

Alves, André Azevedo, y Moreira, José Manuel (2013), The Salamanca School, Bloomsbury, Nueva York.

Aristóteles (1985), Ética nicomáquea, Traducción: Julio Pallí, Gredos, Madrid.

Aristóteles (1988), Política, Traducción: Manuela García, Gredos, Madrid.

Baeck, Louis (1994), The Mediterranean Tradition in Economic Thought, Routledge, Londres.

Barrientos, José (2001), “Los tratados 'De Legibus' y 'De Iustitia el iure' en la Escuela de Salamanca de los siglos XVI y XVII", Salamanca: Revista de estudios, $\mathrm{n}^{\circ} 47$, pp. 371-415.

Barrientos, José (2005), “Aproximación histórica al concepto 'Escuela de Salamanca”, Salmanticensis, no 52, pp. 69-119.

Barrientos, José (2011), Repertorio de moral económica (1526-1670). La Escuela de Salamanca y su proyección, Eunsa, Pamplona. 
Belda Plans, Juan (2000), La Escuela de Salamanca y la renovación de la teología en el siglo XVI, Biblioteca de Autores Cristianos, Madrid.

Beltrán de Heredia, Vicente (1932-1935, 1952), Francisco de Vitoria. Comentarios a la 'Secunda Secundae' de Santo Tomás, 6 vols., Biblioteca de Teólogos Españoles, Salamanca, Asociación Francisco de Vitoria, Madrid.

Brufau Prats, Jaime (1957), "La noción analógica del 'dominium' en Santo Tomás, Francisco de Vitoria y Domingo de Soto", Salmanticensis, vol. 4, no 1, pp. 96-136.

Carpintero, Francisco (2008), La ley natural. Historia de un concepto controvertido, Encuentro, Madrid.

Castillo, Genara y Zorroza, M. Idoya (2015), “Actividad económica y acción moral. Una revisión del supuesto antropológico moderno en la descripción del mercado de Francisco de Vitoria", Revista Empresa y Humanismo, vol. $19, \mathrm{n}^{\mathrm{o}} 1$, pp. 65-92.

Cendejas, José Luis (2017), "Economics, chrematistics, oikos and polis in Aristotle and St. Thomas Aquinas", The Fournal of Philosophical Economics, vol. $\mathrm{X}, \mathrm{n}^{\circ} 2$, pp. 5-46.

Cruz, Juan (ed.) (2008), Ley y dominio en Francisco de Vitoria, Eunsa, Pamplona.

Cruz, Juan (2017), El dominio de las cosas según Vitoria, Editorial Universidad Francisco de Vitoria, Pozuelo de Alarcón.

Folgado, Avelino (1959), "Los tratados De Legibus y De Iustitia et Iure en los autores españoles de los siglos XVI y XVII", La Ciudad de Dios, n 172, pp. 275-302.

Font, Cecilia (2006), "La racionalidad económica en la Escuela de Salamanca: Francisco de Vitoria y Luis de Molina”, Mediterráneo Económico, n 9 , pp. 153-163.

Font, Cecilia (2010), "The School of Salamanca: Some Thoughts on the Subject of Justice", en Parisi, Daniela y Solari, Stefano (eds.), Humanism and Religion in the History of Economic Thought. Selected Papers from the 10th Aispe Conference, Franco Angeli, Milán, pp. 96-112.

Frayle, Luis (2001), Francisco de Vitoria. La justicia (qq. 57-61, 1535), Tecnos, Madrid. 
Fuentes Quintana, Enrique (ed.) (1999), "La Escuela de Salamanca y las ideas económicas de la Escolástica", Economía y Economistas Españoles, vol. 2, Galaxia Gutenberg, Barcelona, pp. 101-354.

Gómez Camacho, Francisco (ed.) (1981), Luis de Molina. La teoría del justo precio, Editora Nacional, Madrid.

Gómez Camacho, Francisco (1998), Economía y filosofía moral: la formación del pensamiento económico europeo en la Escolástica española, Síntesis, Madrid.

Gómez Camacho, Francisco (1999), "El pensamiento económico en la Escuela de Salamanca”, en Fuentes Quintana, Enrique (ed), Economía y economistas españoles, vol. 2, pp. 177-207.

Gómez Rivas, León (2002), "Marjorie Grice-Hutchinson y los orígenes del liberalismo en España”, La Ilustración Liberal, n 11, pp. 81-90.

Gómez Rivas, León (2004), La Escuela de Salamanca, Hugo Grocio y el liberalismo económico en Gran Bretaña, Tesis Doctoral dirigida por Victoriano Martín, Universidad Complutense de Madrid, Madrid.

Gómez Rivas, León (2005a), "Economía y guerra: el pensamiento económico y jurídico desde Vitoria a Grocio (y después)", Studia bistorica. Historia moderna, $\mathrm{n}^{\circ} 27$, pp. 135-159.

Gómez Rivas, León (2005b), "La Escuela de Salamanca, Hugo Grocio y el liberalismo", Torre de los Lujanes, no 55, pp. 217-228.

González Fabre, Raúl (1998), Justicia en el mercado. La fundamentación de la ética del mercado según Francisco de Vitoria, Universidad Católica Andrés Bello, Caracas.

Gordon, Barry (1975), Economic Analysis before Adam Smith: from Hesiod to Lessius, MacMillan Press, Londres.

Grice-Hutchinson, Marjorie (1952), The School of Salamanca: Readings in Spanish Monetary Theory, 1544-1605, Clarendon Press, Oxford. Edición en español: Perdices, Luis, Ramos, José Luis y Reeder, John (ed.), La Escuela de Salamanca: una interpretación de la teoría monetaria española, 1544-1605, Caja España, Salamanca, 2005.

Grice-Hutchinson, Marjorie (1978), Early Economic Thought in Spain, 1177-1740, Allen \& Unwin, Londres. Traducción (1982) El pensamiento económico en España, 1177-1740, Crítica, Barcelona. 
Grice-Hutchinson, Marjorie (1989), "El concepto de Escuela de Salamanca: sus orígenes y desarrollo", Revista de Historia Económica, vol. VII, nº 2, pp. 21-26.

Grice-Hutchinson, Marjorie (1993), Economic Thought in Spain: Selected Essays of Marjorie Grice-Hutchinson, Edward Elgar, Aldershot. Traducción (1995) Ensayos sobre el pensamiento económico en España, Alianza Editorial, Madrid.

Grice-Hutchinson, Marjorie (1999), "En torno a la Escuela de Salamanca", en Fuentes Quintana, Enrique (ed.), Economía y economistas españoles, vol. 2, pp. 163-176.

Iparraguirre, Demetrio (1957), Francisco de Vitoria. Una teoría social del valor económico, Publicaciones de la Universidad de Deusto, Mensajero, Bilbao.

Lagares, Manuel J. (2016), "Seis incógnitas y algunas respuestas sobre la vida de Fray Tomás de Mercado", Iberian Fournal of the History of Economic Thought, vol. 3, n ${ }^{\circ}$, pp. 68-77.

Langella, Simona (2011), Teología y ley natural, estudio sobre las lecciones de Francisco de Vitoria, Biblioteca de Autores Cristianos, Madrid.

Larraz, José [1943 (1963)], La época del mercantilismo en Castilla, 15001700, Aguilar, Madrid.

Martín, Victoriano (1999), "La controversia sobre los pobres en el siglo XVI y la doctrina sobre la propiedad", en Fuentes Quintana, Enrique (ed.), Economía y economistas españoles, vol. 2, pp. 295-339.

Martín, Victoriano (2000), "Análisis económico y Economía Aplicada en el pensamiento económico español de los siglos XVI y XVII”, Cuadernos de Ciencias Económicas y Empresariales, $\mathrm{n}^{\circ}$ 37, pp. 33-49.

Osuna, Antonio; Cordero, Jesús; Mantovani, Mauro; Hernández, Ramón; Langella, Simona y Martínez, Ángel (eds.) (2017), Francisco de Vitoria. Relecciones jurídicas y teológicas, 2 vols., San Esteban, Salamanca.

Pena González, Miguel Anxo (2009), La Escuela de Salamanca, de la Monarquía hispánica al Orbe católico, Biblioteca de Autores Cristianos, Madrid.

Perdices de Blas, Luis (ed.) (2008), Historia del pensamiento económico, Síntesis, Madrid. 
Reeder, John (2008), "El pensamiento económico de los escolásticos", en Perdices de Blas, Luis (ed.), Historia del pensamiento económico, Síntesis, Madrid, pp. 21-41.

Roover, Raymond de (1955), "Scholastic Economics: Survival and Lasting Influence from the Sixteenth Century to Adam Smith", Quarterly fournal of Economics, vol. 69, $\mathrm{n}^{\mathbf{0}}$ 2, pp. 161-190.

Rothbard, Murray N. (1995), Economic Thought before Adam Smith: An Austrian Perspective on the History of Economic Thought, Edward Elgar, Cheltenham (UK). Traducción (1999, 2000) Unión Editorial, Madrid.

Schumpeter, Joseph A. (1954), History of Economic Analysis, Oxford University Press, Oxford. Traducción Sacristán, Manuel; García Durán, José Antonio y Serra, Narciso (eds.) (2008), Historia del análisis económico, Ariel, Barcelona.

Sierra Bravo, Restituto (1975), El pensamiento social y económico de la Escolástica desde sus orígenes al comienzo del Catolicismo social, CSIC, Instituto de Sociología Balmes, Madrid.

Tedde, Pedro y Perdices de Blas, Luis (1999), "La Escuela de Salamanca en el siglo XVI español”, en Fuentes Quintana, Enrique (ed.), Economía y economistas españoles, vol. 2, pp. 101-130.

Tomás de Aquino [1267-1273 (2001)], Suma de Teología, Biblioteca de Autores Cristianos, Madrid.

Vigo, Abelardo del (1997), Cambistas, mercaderes y banqueros en el Siglo de Oro español, Biblioteca de Autores Cristianos, Madrid.

Vilar, Pierre (1969), Oro y moneda en la bistoria, 1450-1920, Ariel, Barcelona.

Zorroza, M. Idoya (ed.) (2006), Francisco de Vitoria. Contratos y usura, Eunsa, Pamplona.

Zorroza, M. Idoya (2011), "Notas sobre la antropología del 'dominio rei' en Francisco de Vitoria", Recherches Philosophiques, n 7, pp. 105-126.

Zorroza, M. Idoya (2013), "Hacia una delimitación de la Escuela de Salamanca", Revista Empresa y Humanismo, vol. 16, n 1, pp. 53-72.

Zorroza, M. Idoya (2016), "Francisco de Vitoria and the Problems of Dominion and Justice". En Espiña, Yolanda (ed.), Images of Europe. Past, Present, Future, pp. 314-321, Universidade Católica, Oporto. 
